\begin{tabular}{|c|c|c|c|}
\hline \multirow{3}{*}{$\begin{array}{r}\text { Case Reports in } \\
\text { Gastroenterology }\end{array}$} & \multirow{2}{*}{\multicolumn{2}{|c|}{ Case Rep Gastroenterol 2018;12:528-531 }} & \multirow[b]{3}{*}{$\begin{array}{l}\text { Karger } \\
\text { Open'access }\end{array}$} \\
\hline & & & \\
\hline & $\begin{array}{l}\text { DOI: 10.1159/000490041 } \\
\text { Published online: August 31, } 2018\end{array}$ & $\begin{array}{l}\text { (c) } 2018 \text { The Author(s) } \\
\text { Published by S. Karger AG, Basel } \\
\text { www.karger.com/crg }\end{array}$ & \\
\hline & $\begin{array}{l}\text { This article is licensed under th } \\
\text { International License (CC BY-NC) } \\
\text { Usage and distribution for commer }\end{array}$ & $\begin{array}{l}\text { nons Attribution-NonCommercia } \\
\text { ger.com/Services/OpenAccessLic } \\
\text { uires written permission. }\end{array}$ & \\
\hline
\end{tabular}

\title{
Jejunal Serrated Adenoma Diagnosed and Treated by Double-Balloon Enteroscopy
}

\author{
Anning Yin ${ }^{a} \quad Z_{\text {hi Zeng }}^{b} \quad$ Xinyue Wan ${ }^{a}$ Honggang Yu ${ }^{a} \quad$ Liang Zhao \\ ${ }^{a}$ Department of Gastroenterology, Renmin Hospital of Wuhan University, Wuhan, China; \\ ${ }^{b}$ Department of Pathology, Renmin Hospital of Wuhan University, Wuhan, China
}

\section{Keywords}

Serrated adenoma $\cdot$ Jejunum $\cdot$ Double-balloon enteroscopy

\begin{abstract}
Serrated polyps are most commonly located in the colorectum and have been well recognized as an important precursor lesion for colorectal cancer. Serrated adenoma in the small intestine has been reported more rarely but may represent a distinct morphological and biological subtype with malignant potential. Here, we present the case of a 65 -year-old female who underwent double-balloon enteroscopy due to obscure gastrointestinal bleeding. A polyp sized 3.5 $\times 2.0 \mathrm{~cm}$ with a long pedicle in the jejunum, located $50 \mathrm{~cm}$ distal to the Treitz ligament, was detected. Endoscopic mucosal resection was done. The pathological results revealed a traditional serrated adenoma sized $3.5 \times 2.2 \mathrm{~cm}$.

(c) 2018 The Author(s)

Published by S. Karger AG, Basel
\end{abstract}

\section{Introduction}

Serrated polyps are most commonly detected in the colorectum and characterized by the saw-tooth-shaped infoldings of the surface and crypt epithelium. This distinct polyp subtype was first described by Longacre and Fenoglio-Preiser [1] in 1990 and was categorized histologically into 3 types according to the World Health Organization (WHO) classification: (1) hyperplastic polyp (HP); (2) traditional serrated adenomas (TSAs); and (3) sessile serrated 


\section{Case Reports in Gastroenterology}

Case Rep Gastroenterol 2018;12:528-531

DOI: $10.1159 / 000490041$

2018 The Author

Yin et al.: Jejunal Serrated Adenoma Diagnosed and Treated by Double-Balloon Enteroscopy

adenoma/polyps (SSA/Ps) [2]. Serrated adenoma is well recognized as a precursor lesion accounting for $10-30 \%$ of all colorectal carcinomas with a neoplastic pathway different from the traditional adenoma-carcinoma sequence [3]. Serrated polyps need to be carefully sought in the colorectum because they are an important risk factor for interval colorectal cancer [4]. Serrated adenoma in the small intestine have been reported much less frequently and are localized predominantly in the duodenum. Although the morphology of duodenal serrated adenoma resembles that of TSAs of the colon and rectum, the biomolecular alterations and biological behaviors indicate a distinct subtype with more aggressiveness and a higher malignant potential $[5,6]$. Here, we present a case of jejunal polyp detected by double-balloon enteroscopy (DBE) because of obscure gastrointestinal bleeding (OGIB). Endoscopic mucosal resection (EMR) was done, and the pathologic result revealed TSAs.

\section{Case Presentation}

A 65-year-old female was admitted to the department of gastroenterology because of melena. An 8-year history of melena existed. Melena recurred without regularity, and there was no hematemesis, palpitation, dizziness, fever, or weight loss. The former results of the esophagogastroduodenoscopy (EGD) and colonoscopy were normal. The outcomes of the physical examination on admission were not abnormal. The laboratory data showed a hemoglobin concentration of $11.24 \mathrm{~g} / \mathrm{dL}$ (normal range: 12.0-16.0). The patient underwent EGD and colonoscopy again, and no abnormalities responsible for the bleeding were detected. The patient was diagnosed as OGIB and subsequently underwent DBE.

Total enteroscopy was achieved with a combination of the oral and anal insertion route (anterograde and retrograde). A polyp sized $3.0 \times 2.0 \mathrm{~cm}$ with a long and thick pedicle in the jejunum that was located $50 \mathrm{~cm}$ distal to the Treitz ligament was found. This polyp was smooth and without signs of ulcer, active, and recent bleeding. No additional abnormal findings were detected. This polyp was considered the most likely reason for melena. Therefore, en bloc EMR (Fig. 1) was carried out 1 month later. First, the pedicle of the polyp was injected with a 1:10,000 epinephrine and methylene blue solution to elevate the basal part and reduce the bleeding risk. Second, a nylon-loop was placed around the pedicle of the polyp to prevent postoperative bleeding. Third, electrical resection was performed with a $30-\mathrm{mm}$ standard snare. Fourth, hemoclips were applied on the resected base to prevent complications such as delayed bleeding and perforation. There were no complications. The pathologic result was a TSA sized $3.5 \times 2.2 \mathrm{~cm}$ (Fig. 2). The patient was cured and reported no complications during the 6-month follow-up.

\section{Discussion}

Serrated polyps in the gastrointestinal tract other than the colorectum have been reported rarely but may exhibit a more aggressive behavior [7]. Serrated adenomas in the small intestine have been detected predominantly in the duodenum. The first case report of duodenal serrated adenoma was on a surgical specimen of a papillary tumor juxtaposing the papilla of Vater, showing an adenomatous growth with unlocked saw-tooth-like glands with highgrade dysplasia in 2004 [8]. Rosty et al. [5] investigated the pathological, immunohistochemical, and molecular features of a series of 13 serrated adenomas in the small intestine (11 in the duodenum, 1 in the duodenal-jejunal junction, and 1 in the terminal ileum) obtained by 


\section{Case Reports in Gastroenterology}

Case Rep Gastroenterol 2018;12:528-531

DOI: $10.1159 / 000490041$

(c) 2018 T www.karger.com/crg

Yin et al.: Jejunal Serrated Adenoma Diagnosed and Treated by Double-Balloon Enteroscopy

either EGD biopsy or surgical specimen. Forty-six percent (6/13) of the serrated adenomas demonstrated high-grade dysplasia, and transformation of a duodenojejunal junction adenoma to a serrated adenocarcinoma was found in 1 patient. BRAFV600E mutation, which may play an important role in the malignant transformation of colorectal serrated polyps, was absent in all serrated adenomas in this report. More recently, Park et al. [6] report a case of an early adenocarcinoma arising from a traditional serrated adenoma of the duodenum diagnosed and treated by EGD. It was worthy of noting that there was only minimal change in the size and shape in this polyp over 5 years, which indicated a slow-growing nature. Taking all those data together, serrated adenoma in the small intestine may represent a distinct subtype with a higher virulence and malignant potential than colorectal serrated adenoma.

Here, we present a case of a jejunal polyp with a long, thick pedicle detected by DBE. EMR was done, and the pathologic result revealed TSA. Since total enteroscopy examination was carried out in this procedure, this serrated adenoma was considered the only lesion possibly responsible for OGIB. DBE may be the first-line method of examination for suspected bleeding of the small bowel. When the lesion was found, endoscopic treatment could be performed at the same time.

To the best of our knowledge, this is the first case report of a jejunal serrated adenoma and the first case of this kind of lesions detected and resected by DBE. Considering the possibility of a high malignant potential or synchronously growing invasive adenocarcinoma for serrated adenoma in the small intestine, the lesion should be carefully sought during the deep enteroscopy procedure and radically excised under close surveillance.

\section{Statement of Ethics}

The authors have no ethical conflicts to disclose.

\section{Disclosure Statement}

The authors have no conflicts of interest to disclose.

\section{References}

1 Longacre TA, Fenoglio-Preiser CM. Mixed hyperplastic adenomatous polyps/serrated adenomas. A distinct form of colorectal neoplasia. Am J Surg Pathol. 1990 Jun;14(6):524-37.

2 Snover D, Ahnen DI, Burt RW, et al. Serrated polyps of the colon and rectum and serrated polyposis. In: Bosman FT, Carnerio F, Hurban RH, editors. WHO Classification of Tumours of the digestive system. Lyon, France: IARC; 2010. pp. 160-5.

3 East JE, Atkin WS, Bateman AC, Clark SK, Dolwani S, Ket SN, et al. British Society of Gastroenterology position statement on serrated polyps in the colon and rectum. Gut. 2017 Jul;66(7):1181-96.

4 Hetzel JT, Huang CS, Coukos JA, Omstead K, Cerda SR, Yang S, et al. Variation in the detection of serrated polyps in an average risk colorectal cancer screening cohort. Am J Gastroenterol. 2010 Dec;105(12):265664.

5 Rosty C, Campbell C, Clendenning M, Bettington M, Buchanan DD, Brown IS. Do serrated neoplasms of the small intestine represent a distinct entity? Pathological findings and molecular alterations in a series of 13 cases. Histopathology. 2015 Feb;66(3):333-42.

6 Park YK, Jeong WJ, Cheon GJ. Slow-Growing Early Adenocarcinoma Arising from Traditional Serrated Adenoma in the Duodenum. Case Rep Gastroenterol. 2016 Jun;10(2):257-63.

7 Rubio CA. Traditional serrated adenomas of the upper digestive tract. J Clin Pathol. 2016 Jan;69(1):1-5.

8 Rubio CA. Serrated adenoma of the duodenum. J Clin Pathol. 2004 Nov;57(11):1219-21. 


\section{Case Reports in Gastroenterology}

\begin{tabular}{l|l}
\hline Case Rep Gastroenterol 2018;12:528-531 \\
\hline DOI: 10.1159/000490041 & $\begin{array}{l}\text { @ 2018 The Author(s). Published by S. Karger AG, Basel } \\
\text { www.karger.com/crg }\end{array}$ \\
\hline
\end{tabular}

Yin et al.: Jejunal Serrated Adenoma Diagnosed and Treated by Double-Balloon Enteroscopy
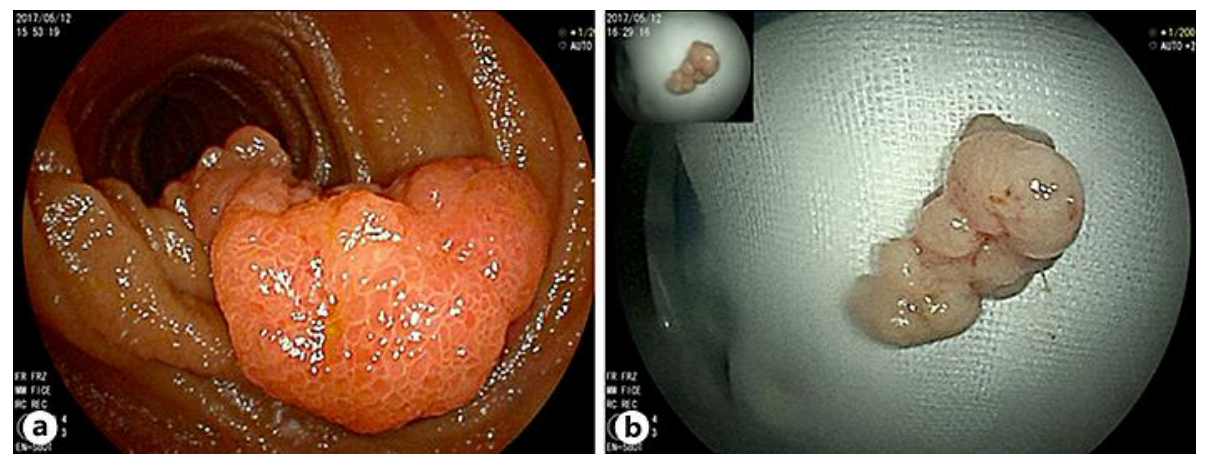

Fig. 1. a View during anterograde DBE showing a polyp sized $3.0 \times 2.0 \mathrm{~cm}$ with a long and thick pedicle in the jejunum that was located $50 \mathrm{~cm}$ distal to the Treitz ligament. b Macroscopic appearance of the polyp, which was completely excised by en bloc EMR.
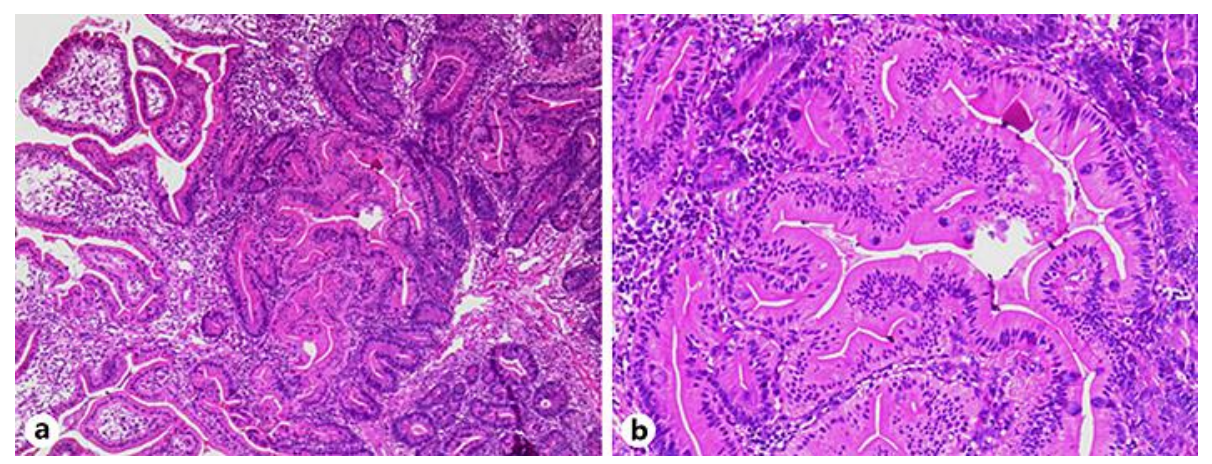

Fig. 2. Histopathological appearance of the hematoxylin and eosin-stained excised mucosal lesion composed of villiform projections of hypereosinophilic cells with small, oval-shaped nuclei oriented basally along the basement membrane. The cells are growing in a hyperserrated luminal contour. Multiple ectopic crypts are present. These are composed of crypts oriented perpendicular to the long axis of the villi. Overall, the goblet cells are decreased in number. Original magnification, $\times 100$ (a) and $\times 400$ (b). 